\title{
IMPACTS OF ILLUMINATION TIME AND COLOR ON TILAPIA OUTGROWTH AND FISH FLESH QUALITY
}

\author{
Atef M. Elsbaay ${ }^{1}$
}

\section{ABSTRACT}

The present study was aimed to look at the impacts of illumination time and illumination color on outgrowth and activity of Nil Tilapia (Tilapia Niloticus). A commercial food was used for feeding fish during experimental period. The data obtained from the experiment were subjected to one-way analysis of variance (ANOVA) (using SPSS program). The results indicated that illumination time (24, 16 hour and control) and illumination colors (white, red and blue) were significantly affected on fish activity. The fish outgrowth at illumination blue was higher than other illumination colors for all illumination time. The illumination blue and long illumination time (24 light hours) created the top fish percentage weight gained during feeding period ( $W G D F P=52.9$ $g)$, specific growth rate $(S G R=4.08 \%)$, daily growth rate $(D G R=17.63$ $\%)$ and growth efficiency $(G E=29 \%)$. On the other side, the blue illumination and short illumination time $16 \mathrm{~h}$ created weight gained during feeding period ( $W G D F P=46.5 \mathrm{~g})$, specific growth rate $(S G R=$ $3.89 \%)$, daily growth rate $(D G R=15.51 \%)$ and growth efficiency $(G E$ $=28 \%)$. At long illumination time, the feed conversation efficiency (FCE) was 92, 95 and $98 \%$ at illumination white, red and blue respectively. There were significant differences in crude protein and crude fat contents among fish exposed to different photoperiod regimes. Fish exposed to $(24 \mathrm{~h})$ illumination regime had significantly lower crude fat and ash than those of the other.

Keywords: illumination, colors, fish, outgrowth, quality, protein

\section{INTRODUCTION}

quaculture has been growing steadily in recent times as an
excellent source of high-quality protein. It is growing at $9 \%$
every year and it is estimated to grow up to $41 \%$ (53.6 million tons) of the fish production worldwide by the year 2020 (Krishen et al.,

${ }^{1}$ Lecturer Agric. Eng. Dept., Faculty of Agric., Kafrelsheikh University, Egypt. E-mail: atef.ahmed@agr.kfs.edu.eg 
2009). Tilapia culture is a fast growing commercial endeavour and these fishes have emerged as the third most important cultured fish commodity in the world, next to carps and salmonids (FAO, 2005). During culture, growth performance of this species has been controlled by the manipulation of food ingredients (Hu et al., 2006), addition of growth promoters (Lara-Flores et al., 2003) and manipulation of environmental conditions (Vera Cruz and Brown, 2009 and Fuentes-Silva et al. 2015)

The intensive culture of tilapia under controlled management systems is widely expanding to meet the increasing demands for these fishes, especially in developing countries. In this regard, the use of closed culture systems has received a considerable attention, and is becoming more common worldwide, particularly in arid areas that face shortage in fresh water or brackish water, or in areas where environmental parameters, such as salinity and temperature, are outside the tolerance range of tilapia (El-Sayed and Kawanna, 2004).

Light rays of various wavelength pass through the water to different depths depending on light reflection, absorption and diffusion as well as on availability of admixtures and small organisms in a water body. Photoperiod acts as an artificial Zeitgeber (cue or synchronizer), regulating the daily endogenous rhythms in fish and also affects fish growth, metabolic rates, body pigmentation, sexual maturation and reproduction (Biswas et al., 2002; Biswas et al., 2005). On the other hand, the growth and metabolic rates of several other species were not significantly affected by photoperiods (Purchase et al., 2000 and Elsbaay, 2013). Meanwhile, photoperiod may positively affect larval stages, but not juvenile stages.

Adaptations of fish to their natural environment may also influence their response to the farming environment. As in nature, light intensity and background color can affect feed detection and feeding success of cultured fish, thus influencing fish growth and mortality. In general, the highest growth rates of fish larvae are achieved when light conditions and background color optimize the contrast between the feed and the background (Jentoft et al., 2006; Strand et al., 2007). Light intensity may also affect the size of prey preferred by juvenile fish. 
In most studies fluorescent lamps are used, resulting in what humans perceive as white light, despite the fact that: (a) in natural fish habitat, wavelength of light penetrating water varies greatly, (b) fish vision and spectrum perception are strongly adapted to each species natural habitat and living ethology (Pointer et al., 2005), and (c) recent studies indicate that light spectrum affects farmed fish growth performance (Karakatsouli et al., 2008), behavior (Marchesan et al., 2005) and physiological status (Karakatsouli et al. 2010).

Knowledge of the chemical composition of fish is necessary for a more effective introduction in the market, allowing competition with other widely consumed sources of animal protein, as beef, pork and poultry (Kristinsson and Rasco, 2000). The yield in fillet a fish depends on the weight, sex, body composition, anatomical features (relative head / body), mechanization level in the process, filleting method and skill of the operator (Clement and Lovell, 1994). As for the nutritional aspect, it is important to know the chemical composition of fish for consumption is stimulated, allowing competition with other protein sources widely used such as beef, pork and poultry (Garduno-Lugo et al., 2003). The photoperiod in addition to stimulating growth, can lead to changes in the chemical composition of fish (Biswas et al., 2005), since it influences the development and survival in different ontogenic phase. In addition, photoperiod influences both the feeding strategies as in the stimulation of the metabolic activities of various fish (Biswas et al., 2002). For some species, days or long photoperiods may indirectly modify the growth is by inducing an increase feed intake, dough development muscle due to the increased locomotor activity of animals, better efficiency in the use of nutrients and due to diversion of energy from maturation to somatic growth ( $\mathrm{Rad}$ et al., 2006). However, there is little information on the effects of environmental factors on the chemical composition of fish, such as Nile tilapia, at different stages of production.

The present study aimed to, firstly, clear the impacts of illumination color and illumination time on outgrowth and activity of fish (Nil Tilapia). Secondly, study the fish flesh quality through chemical composition of fish. 


\section{MATERIALS AND METHODS}

\subsection{Experimental design:}

The experimental system was constructed and carried out in the Kafr ElSheikh Governorate, Egypt $\left(30.95^{\circ} \mathrm{N}\right.$ and $31.9^{\circ} \mathrm{E}$, and $9.0 \mathrm{~m}$ above the sea level) through the period $1^{\text {st }}$ March, 2016 to $1^{\text {st }}$ May, 2016. The experiments were studied 84 Nile tilapia fingerlings with initial weight 5 $\mathrm{g}$ in glass tanks (21 tanks). Experimental tanks (length $\times$ height $\times$ width: $0.7 \times 0.5 \times 0.35 \mathrm{~m}$, volume capacity $0.1225 \mathrm{~m}^{3}$ ), the tanks were provided with central drainage pipes surrounded by outer sleeves pipes, perforated at the bottom, to facilitate self-cleaning and waste removal. Continuous aeration through an air pump (Boyu, U -9900, $3.21 / \mathrm{mint}$ ) and heaters, with thermostats, to keep water temperature at 26 ${ }^{\circ} \mathrm{C}$. Fig. 1 shows the schematic diagram of experimental design. About $20 \%$ of the water was replaced daily by new fresh water at the same temperature. Water quality parameters, including dissolved oxygen (DO), ammonia and $\mathrm{pH}$ were recorded every ten days.

The examination was intended to study the impact of illumination time and illumination color on Nile tilapia outgrowth, feed utilization efficiency and survival of Nile tilapia. The fish were exposed to two illumination time ( 24 and $16 \mathrm{~h}$ ) by using fluorescent lamps and natural daylight (control, at experiment starting $11 \mathrm{~h} 37 \mathrm{mint}$ and experiment end $13 \mathrm{~h} 24$ mint). Illumination in each treatment was provided by two fluorescent lamps (36 W) suspended about $1 \mathrm{~m}$ above the water surface. On the other side, the fish were exposed to three types of illumination color (whit, red and blue). Light intensity was measured every ten days at water surface (at tank center) by a digital Lux Meter (Digital light meter Nicety LX-802) and was constant at around $400 \mathrm{~lx}$ throughout the experiment in artificial illumination groups. Light color (red $605 \mathrm{~nm}, 90 \%$ relative transmission; blue $480 \mathrm{~nm}, 83 \%$ relative transmission; white fullspectrum) and control was applied as previously described (Karakatsouli et al., 2008).

Fish were acclimated to experimental tanks for 1 day under room ambient lighting. After the acclimation period white, red and blue light color and photoperiod were applied and fish remained in these conditions for 60 days. Light color was achieved by covering light 
source. The fish were fed by hand a commercial feed (crude protein, 27 $\%$; crude lipid $5.06 \%$; crude fiber $5.08 \%$; total energy $4000 \mathrm{kcal} / \mathrm{kg}$ ) for 60 days. The diet was offered twice a day at 10:00 h and 16:00 h. Daily feeding rates (\% BW/day) were determined based on recommendations of different researchers (El-Sayed, 2002).

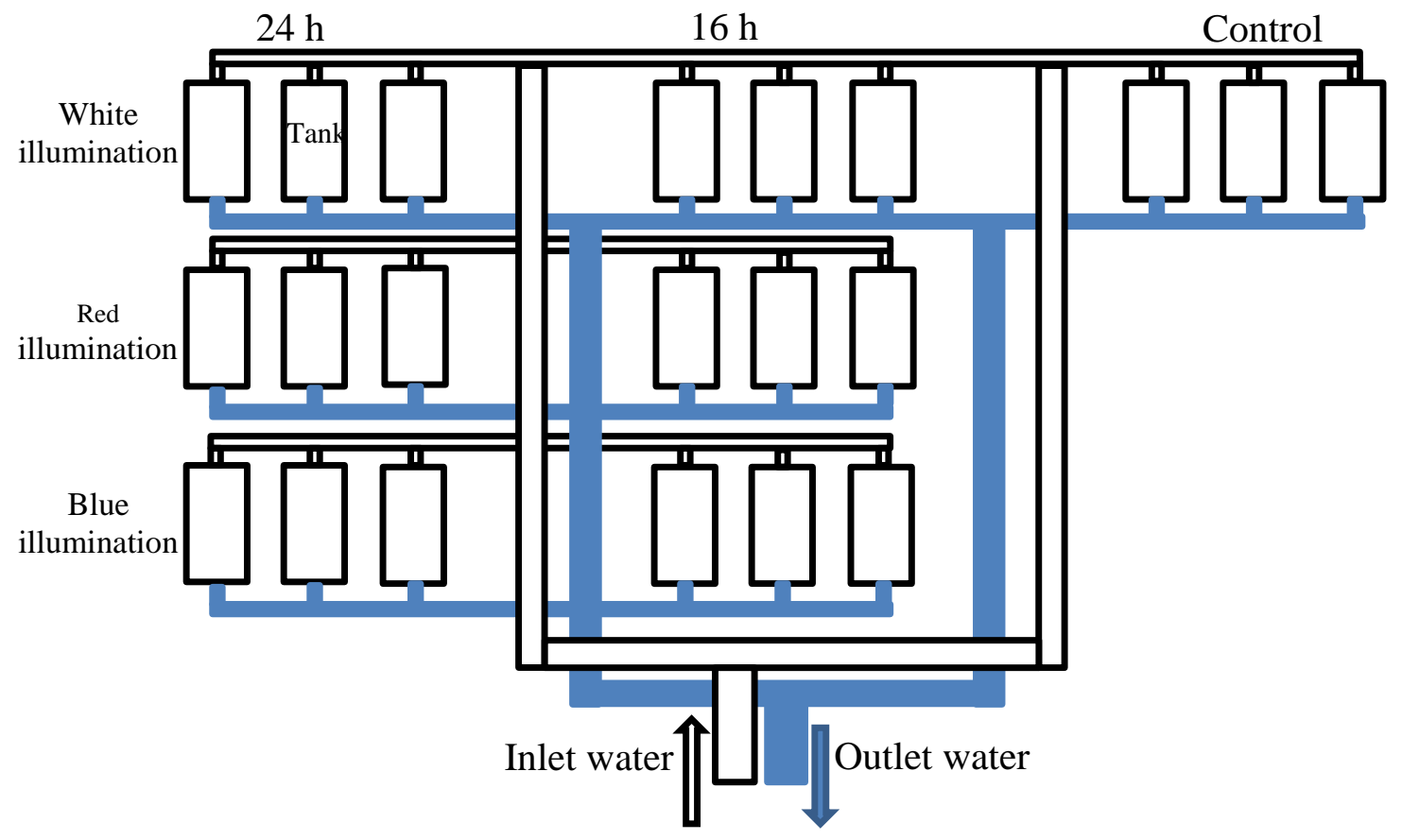

Fig. 1: Schematic diagram of the experimental design.

\subsection{Grow-out performance analysis:}

Therefore, the daily rates were of $6 \% \mathrm{BW} /$ day for 30 days and reduced to $5 \% \mathrm{BW} /$ day for other 30 days. Fish were weighed at 10 days intervals (days: $0,10,20,30,40,50$ and 60) and feed intake were adjusted every 10 days also. Fish were weighed using an electronic balance (Shimadzu, EB-620SU $\pm 0.01 \mathrm{~g}$ sensitivity). The data collected every ten days and the growth rates were measured in terms of specific growth rate (SGR), weight gain during feed period (WGDFP), feed conversation efficiency (FCE) and condition factor $(\mathrm{K})$ as the following (FuentesSilva et al. 2015): 


$$
W G D F P=F W-I W
$$

Where:

$$
\begin{gathered}
\mathrm{FW}=\text { final weight, } \mathrm{g} . \\
D G R=\frac{F W-I W}{\text { experimental period } \times I W} \times 100
\end{gathered}
$$

Where:

$$
\begin{gathered}
\text { DGR }=\text { daily growth rate, } \% \\
S G R=\left(\frac{\ln F W-\ln I W}{\text { time }(\text { day })}\right) * 100 \\
F C E=\frac{\text { mass gained }(g)}{\text { total amount of feed consumed }(g)}
\end{gathered}
$$

To evaluate energy expenditure, the energetic growth efficiency (GE) was calculated, where GE is the ratio between the energy of the weight increase of the fish and the total energy intake of the fish (Larsson and Berglund, 2005):

$G E=\frac{(J \times(F W-I W))}{(F I \times D E)}$

Where: $\mathrm{J}$ is the conversion factor of mass to energy for percids $\left(5.0 \mathrm{~kJ} \mathrm{~g}^{-1}\right.$ wet weight) (calculated average from Bryan et al., 1996),

FI is the feed intake (g), and DE is the digestible energy content of the feed $\left(16.747 \mathrm{~kJ} \cdot \mathrm{g}^{-1}\right.$, obtained from the manufacturer).

\subsection{Body composition analysis:}

Chemical composition of Nile Tilapia flesh (moisture; crude protein; lipid and ash) was estimated using the AOAC (2000) methods. Amino acids determination: Amino acids of isolated protein were determined in agricultural Res., Center, Cairo, based to the method described by Pellet and Young (1980).

\subsection{Statistical analysis:}

The data obtained from the experiment were subjected to one-way analysis of variance (ANOVA) (using SPSS program) to test the effect of 
photoperiod and light color on the growth rates, feed utilization efficiency. When ANOVA identified significant difference among groups. Least significant difference (LSD) was used to compare means at $\mathrm{P}<0.05$.

\section{RESULTS AND DISCUSSION}

\subsection{Water quality management:}

Results indicated that the water parameters (salinity, temperature, hardness, $\mathrm{pH}$, ammonia, nitrite and dissolved oxygen) in water used for breeding of Nile Tilapia. The water temperature in the all ta of the experiment ranged from 23 to $28{ }^{\circ} \mathrm{C}, \mathrm{pH}$ degree ranged from 7.6 to 7.8 , dissolved oxygen ranged from 6.50 to $7.4 \mathrm{ppm}$, nitrite ranged from 0.02 to $0.14 \mathrm{ppm}$, nitrate ranged from 1.8 to $2.3 \mathrm{ppm}$, ammonia 0.13 to 0.19 and the salinity level in the experiment not changed and reached to 1 ppm. The present results also showed that, the recorded levels of water parameters not exceeds the permissible levels required for fish breeding and production.

\subsection{Fish growth performance under different illumination time:}

Data illustrations on growth performance of Nile tilapia exposed to two illumination time are presented in and Fig.2. The results of experiment indicated that illumination time (24 and $16 \mathrm{~h}$ ) and ambient light regime (control) significantly affected fish growth performance (Fig. 2 and Fig. $3)$. The continuous illumination time regime $(24 \mathrm{~h})$ created the top mean final weight $50.6 \pm 0.30 \mathrm{~g}$. Mean final weights of fish exposed to illumination time $16 \mathrm{~h}$ and control treatment were measured as $47.3 \pm$ 0.20 and $43.1 \pm 0.20 \mathrm{~g}$, respectively. Consequentially, the weight gained during feed period was higher under continuous illumination regime (24 h) for all color light (45.6, 48.8 and $52.8 \mathrm{~g}$ for white, red and blue respectively). At the end of experiment, there are significant differences between photoperiods $(p<0.05)$. Significant differences in mean body weights of photoperiod groups and control were only detectable during the second month (days 30-60) of the experiment. Throughout this stage, mean body weight of fish at continuous illumination regime $(24 \mathrm{~h})$ was 
significantly different and higher than that of other illumination time regime $(16 \mathrm{~h})$ and control $(\mathrm{p}<0.05)$. Moreover, mean body weights of fish exposed to $16 \mathrm{~h}$ illumination time groups were also found to be significantly different from that of control during this development stage. The results indicated that illumination time was significantly affected fish growth performance (Fig. 3 and Fig. 4). The continuous illumination time regime $(24 \mathrm{~h})$ created the best fish percentage weight gain during feed period $(\mathrm{WGDFP}=45.6 \mathrm{~g})$, specific growth rate $(\mathrm{SGR}=3.86 \%)$, daily growth rate $(\mathrm{DGR}=15.21 \%)$ and growth efficiency $(\mathrm{GE}=27 \%)$. The control treatment created the lowest values of weight gain during feeding period (WGDFP $=38.1 \mathrm{~g}$ ), specific growth rate $(\mathrm{SGR}=3.59 \%$ ), daily growth rate $(\mathrm{DGR}=12.72 \%)$ and growth efficiency $(\mathrm{GE}=25 \%)$. On the other side, the highest mean value of feed conversation efficiency ( $\mathrm{FCE}=92 \%)$ was observed in continuous illumination time regime (24 $\mathrm{h}$ ), while, the lowest mean value of feed conversation efficiency (FCE = $85 \%$ ) was observed in control treatment.

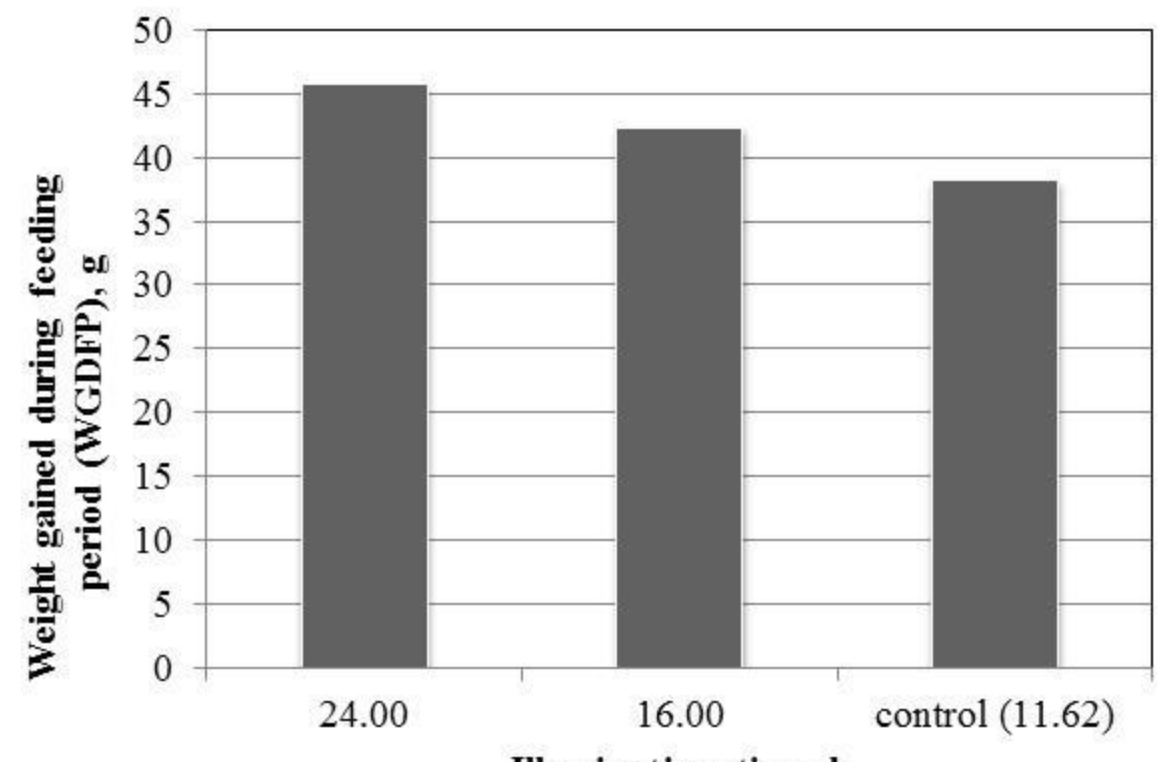

Illumination time, $h$

Fig. 2. Weight gained during feeding period (WGDFP) of Nile tilapia under different illumination time regimes. 


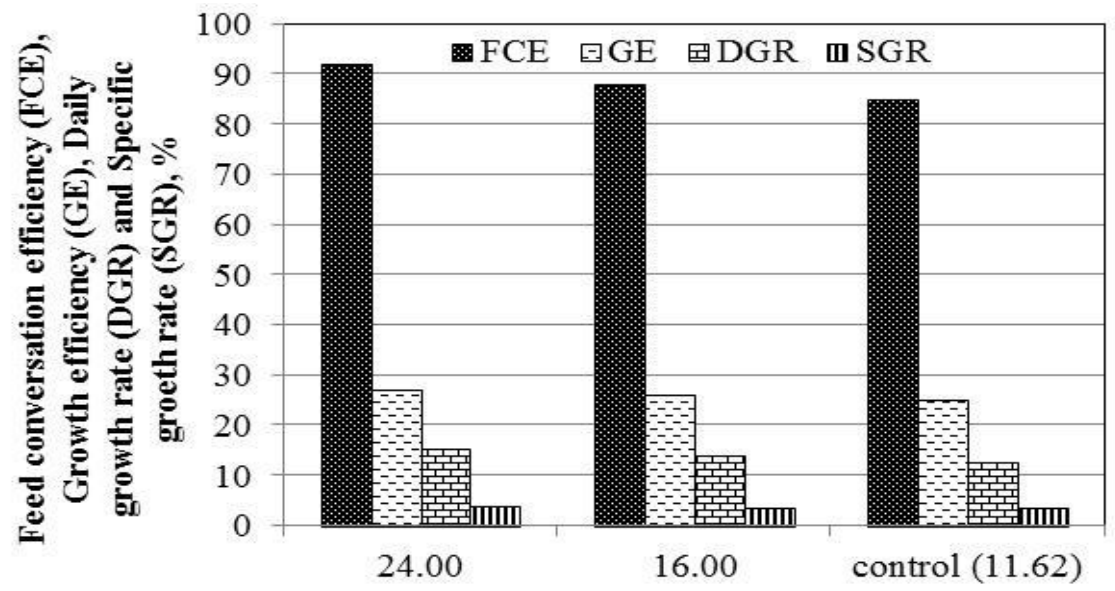

Illumination time, $h$

Fig. 3. The growth performance (FCE, DGR, GE and SGR) of Nile tilapia under different illumination time regimes.
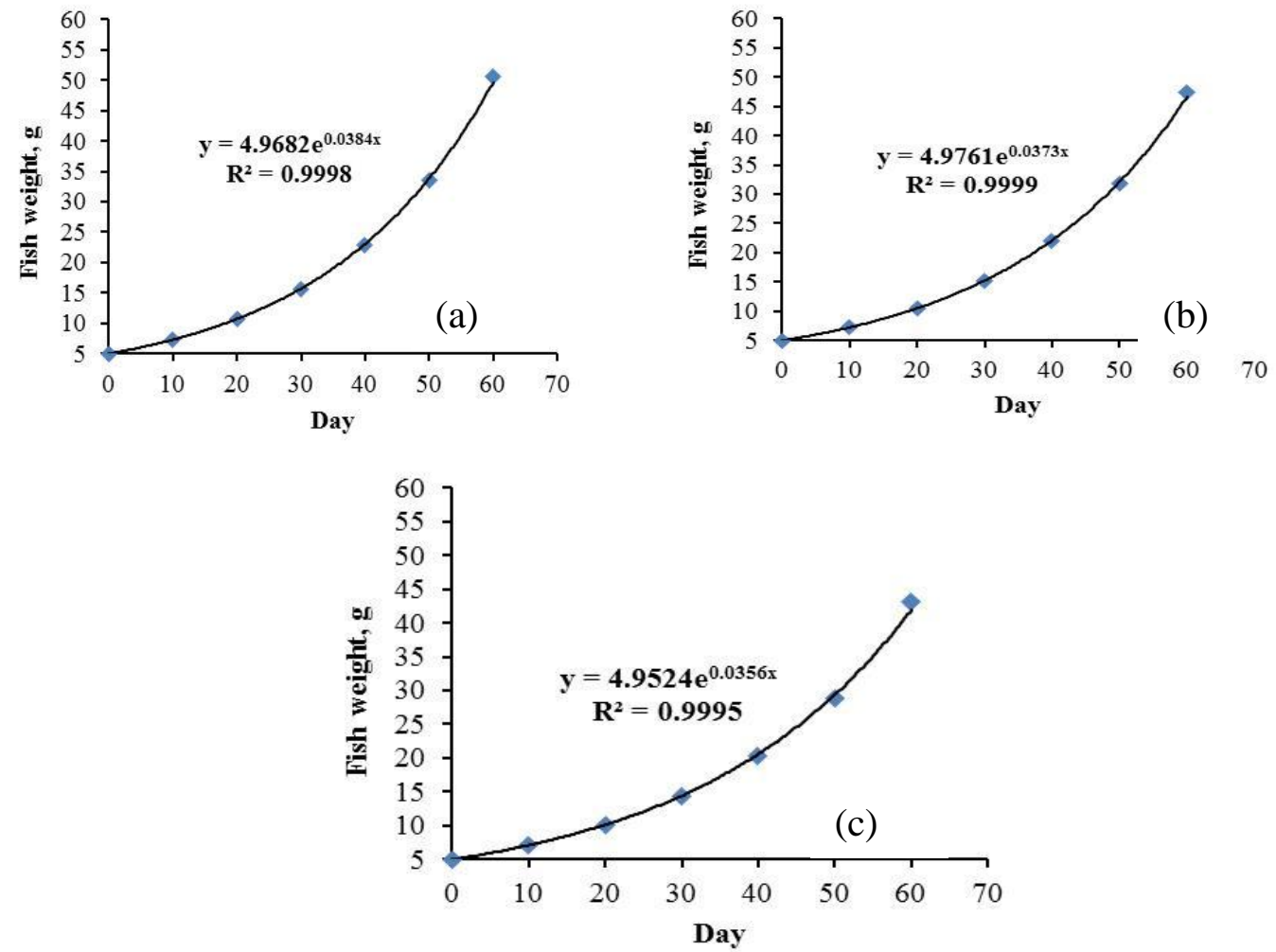

Fig.4: The growth rate fitting curve of Nile tilapia under different illumination time regimes: a) illumination time $24 \mathrm{~h}, \mathrm{~b}$ ) illumination time $16 \mathrm{~h}$ and c) control treatment $11.62 \mathrm{~h}$. 
The results indicated that the relationship between the fish weight $(\mathrm{g})$ and the illumination time (day) was exponential function (Fig. 4). The improvement in the performance of Nile tilapia the present study with increasing illumination time may also have been related to the reduction of standard metabolic rate. In support, (Biswas et al., 2003) studied the effects of illumination time on the metabolic rate of fed and unfed young and adult Nile tilapia. They found that metabolic rate and energy loss were negatively correlated with illumination time. They concluded that Nile tilapia conserve energy when raised under illumination time with longer light phases. However, these authors suggested that growth studies must be conducted under different illumination time cycles in order to further evaluate the effects of photoperiod regimes on these fish. The reduction of fish metabolic rate with increasing light phases has also been reported with marine fish species.

\subsection{Fish growth performance under different illumination color:}

Data illustrations on growth patterns of Nile tilapia exposed to three types of illumination colors and two long-day illumination times are presented in Fig. 5, Fig. 6 and Fig 7. The results of experiment indicated that illumination colors (whit, red and blue) significantly affected fish growth performance (Fig. 5 and Fig. 6).

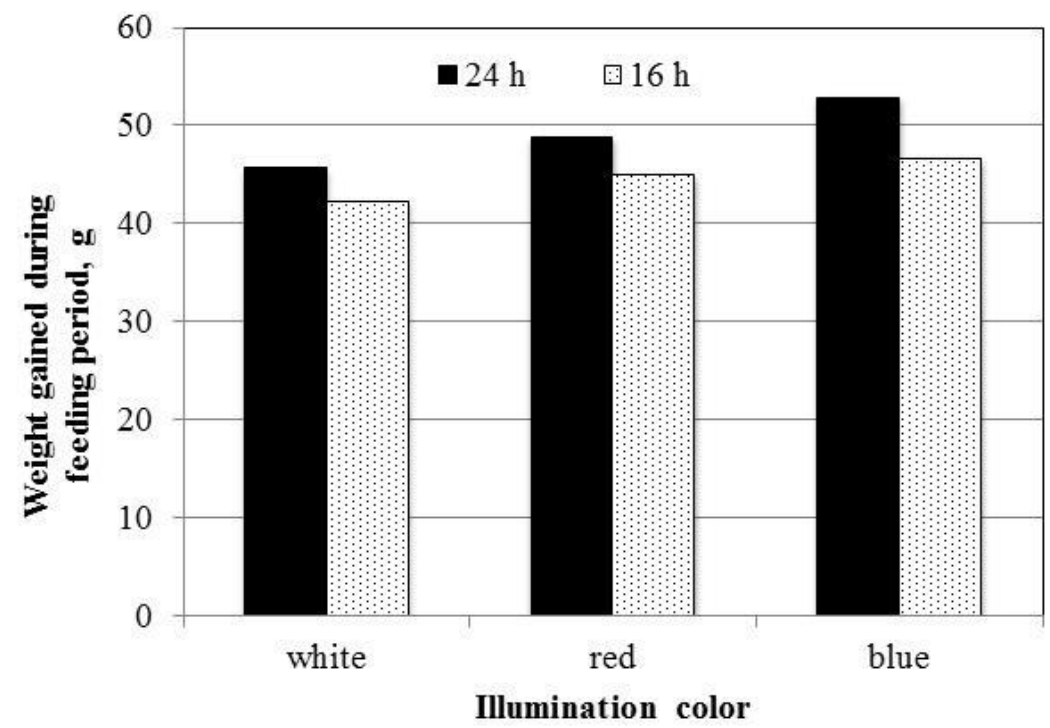

Fig. 5. Weight gained during feeding period (WGDFP) of Nile tilapia under different illumination colors and illumination time regimes. 

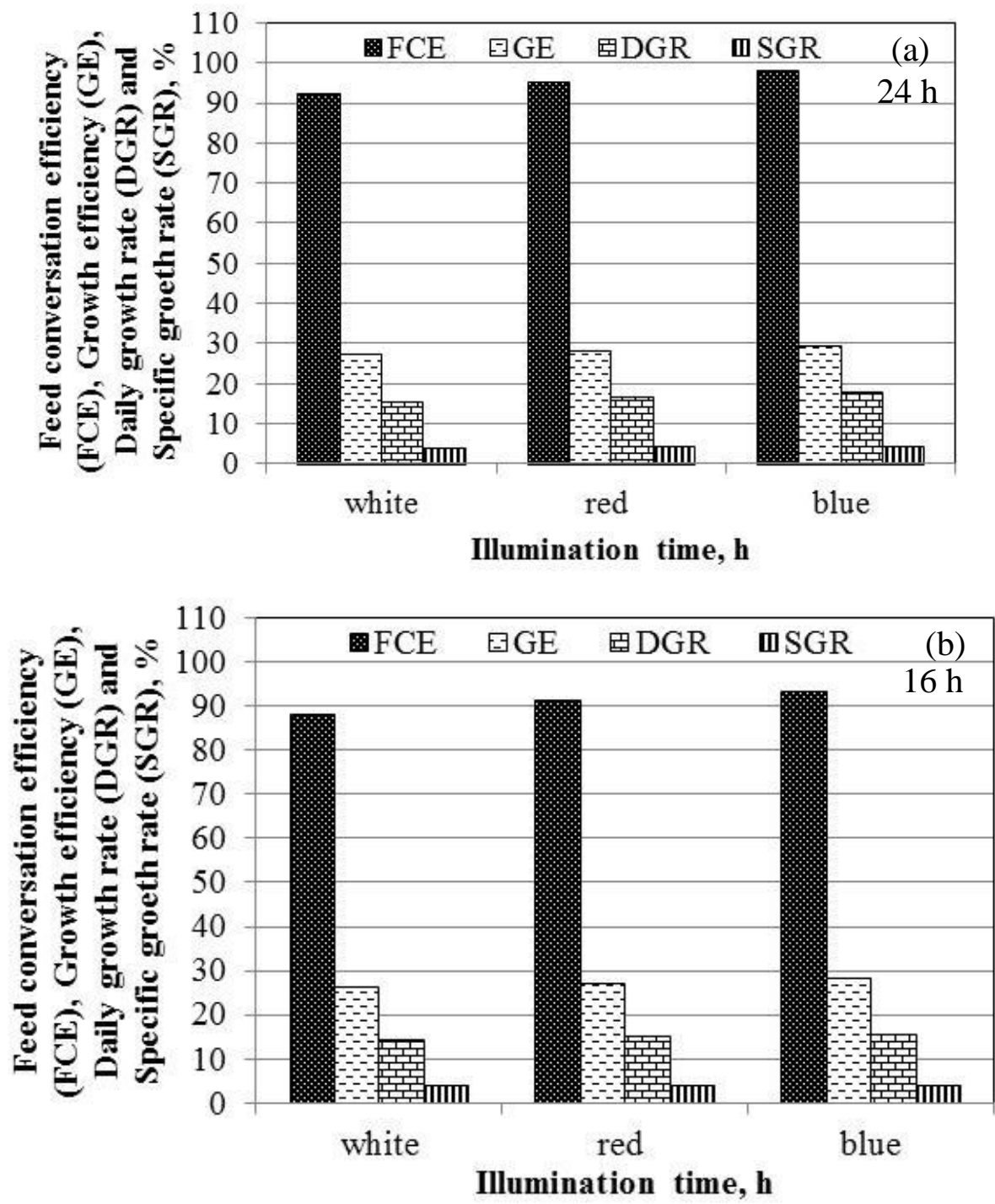

Fig. 6. The growth performance (FCE, DGR, GE and SGR) of Nile tilapia under different illumination color and illumination time regimes (a) $24 \mathrm{~h}$ and (b) $16 \mathrm{~h}$.

The fish maintained under blue illumination and continuous illumination time $(24 \mathrm{~h})$ created the top mean value of final weight $(57.9 \pm 0.4 \mathrm{~g})$. While the mean final weight for fish exposed to blue illumination and 16 $\mathrm{h}$ was $51.5 \pm 0.4 \mathrm{~g}$. Mean final weights of fish exposed to white and red illumination under $24 \mathrm{~h}$ illumination were $50.6 \pm 0.3 \mathrm{~g}$ and $53.8 \pm 0.5 \mathrm{~g}$ 
respectively. On the other side, the mean final weight of fish exposed to white and red illumination under $16 \mathrm{~h}$ were $47.3 \pm 0.2 \mathrm{~g}$ and $49.9 \pm 0.4 \mathrm{~g}$ respectively. There are significant differences between light colors $(\mathrm{p}<$ 0.05). Throughout this experiment, mean body weight of fish at blue light was significantly different and higher than that of other light colors $(\mathrm{p}<0.05)$ both at two photoperiods.

The results indicated that illumination colors significantly affected fish growth performance. At both different illumination times, the blue illumination was best of other illumination colors. The blue illumination and long illumination phase $(24 \mathrm{~h})$ created the best fish percentage weight gain during feeding period (WGDFP $=52.9 \mathrm{~g}$ ), specific growth rate $(\mathrm{SGR}=4.08 \%)$, daily growth rate $(\mathrm{DGR}=17.6 \%)$ and growth efficiency $(\mathrm{GE}=29 \%)$. On the other hand, the blue illumination and illumination time $16 \mathrm{~h}$ gave weight gain during feeding period (WGDFP $=46.5 \mathrm{~g}$ ), specific growth rate $(\mathrm{SGR}=3.89 \%)$, daily growth rate (DGR $=15.51 \%)$ and growth efficiency $(\mathrm{GE}=28 \%)$. The highest mean values of feed conversation efficiency $(\mathrm{FCE}=98 \%$ ) was observed in blue illumination and long illumination time. While, the lowest mean values of feed conversation efficiency $(\mathrm{FCE}=88 \%)$ was observed in white illumination and $16 \mathrm{~h}$ illumination.

The present study demonstrated that the growth and feed efficiency of Nile tilapia were significantly affected by illumination colors. Mean final weights and growth performance (SGR, WGDFP, DGR and GE) of fish exposed to different illumination colors in this study reveal that growth in Nile Tilapia is enhanced under blue illumination when compared to white and red illumination. Light colors have been reported to stimulate growth in a number of fish species (Strand et al., 2007 and Luchiari and Freire, 2009).

It has been suggested that freshwater fish species are more sensitive to photoperiod than marine and diadromous species. However, the response of marine species to photoperiods has been well investigated, while less information is available on freshwater species. 

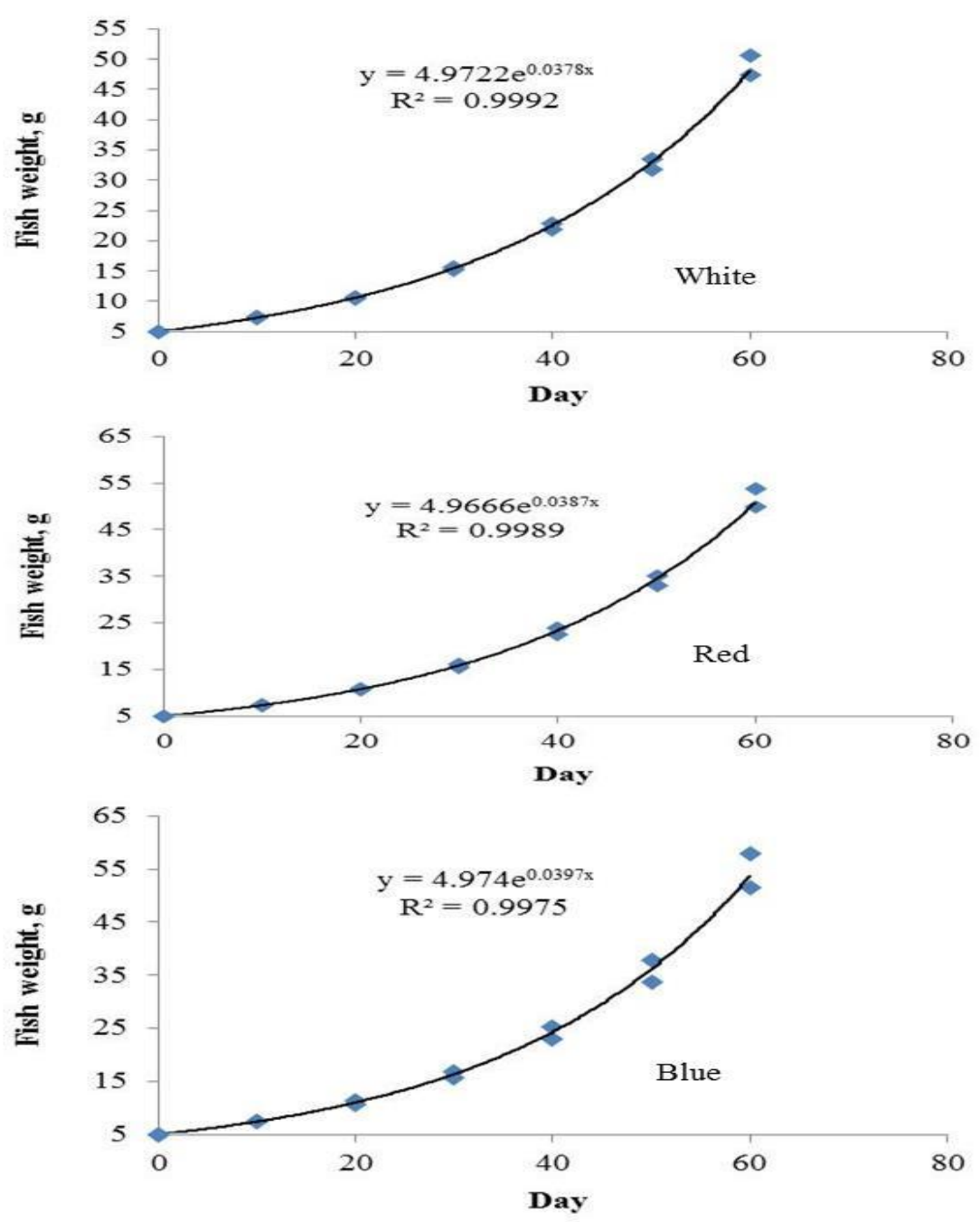

Fig. 7. The growth rate fitting curve of Nile tilapia under different illumination color (white, red and blue).

\subsection{Fish flesh quality:}

There were significant differences in crude protein and crude fat contents among fish exposed to different photoperiod regimes (Table 1). Fish exposed to $(24 \mathrm{~h})$ illumination time regime had significantly lower crude fat and ash than those of the other. Fish exposed to $16 \mathrm{~h}$ illumination time regime had higher body ash and crude fat but lower body protein compared to fish exposed to the $24 \mathrm{~h}$. According to the results, the highest content of protein $55.88 \%$ was found in group blue illumination and long illumination time $(24 \mathrm{~h})$. 
Table: 1. Effect of different Photoperiod and Light Color on the proximate composition (dry weight \%) of Nile Tilapia at the end of the photoperiod trial

\begin{tabular}{|c|l|l|l|l|l|l|l|}
\hline \multirow{2}{*}{$\begin{array}{c}\text { Component } \\
\%\end{array}$} & \multicolumn{6}{|c|}{ Illumination time regime } \\
\cline { 2 - 8 } & \multirow{2}{*}{ Control } & \multicolumn{3}{|c|}{$24 \mathrm{~h}$} & \multicolumn{3}{c|}{$16 \mathrm{~h}$} \\
\cline { 3 - 8 } & & white & red & blue & white & red & blue \\
\hline Moisture & 75.59 & 77.80 & 74.32 & 72.94 & 75.45 & 74.96 & 74.28 \\
\hline Protein & 50.64 & 53.59 & 55.14 & 55.88 & 51.92 & 52.14 & 54.82 \\
\hline Crude fat & 23.70 & 23.52 & 21.95 & 21.74 & 23.81 & 23.67 & 23.32 \\
\hline Ash & 2.04 & 1.97 & 2.01 & 2.12 & 2.00 & 2.05 & 2.10 \\
\hline
\end{tabular}

(Table 2) shows the effect of different illumination time regime and illumination colors on amino acid composition of Nile Tilapia flesh. It could be noticed that, all investigated samples contain almost all types of amino acids. It can be also found that glutamic and Aspartic were the most predominant amino acids. Generally, the highest values for all amino acids were found in fish group blue illumination and long illumination time $(24 \mathrm{~h})$.

Table: 2. Effect of different Photoperiod and Light Color on amino acids content of Nile Tilapia at the end of the photoperiod trial

\begin{tabular}{|l|l|l|l|l|l|l|l|}
\hline \multirow{2}{*}{$\begin{array}{c}\text { Component } \\
\%\end{array}$} & \multicolumn{6}{|c|}{ Illumination time regime } \\
\cline { 2 - 8 } & \multirow{2}{*}{ Control } & \multicolumn{3}{|c|}{$24 \mathrm{~h}$} & \multicolumn{3}{c|}{$16 \mathrm{~h}$} \\
\cline { 3 - 8 } & & white & red & blue & white & red & blue \\
\hline Lysine & 7.67 & 6.93 & 7.54 & 8.92 & 7.13 & 7.23 & 7.21 \\
Iso-leucine & 3.93 & 4.30 & 3.96 & 3.84 & 3.77 & 4.20 & 3.55 \\
Leucine & 7.03 & 7.65 & 8.21 & 7.98 & 7.21 & 7.82 & 7.40 \\
Methionine & 1.60 & 1.56 & 1.21 & 1.71 & 1.68 & 2.60 & 1.68 \\
Phenylalanine & 3.33 & 3.98 & 3.30 & 3.46 & 4.12 & 3.28 & 3.75 \\
Threonine & 3.93 & 4.20 & 3.99 & 5.01 & 4.08 & 3.66 & 3.72 \\
Tryptophan & 1.07 & 1.43 & 1.07 & 4.19 & 1.92 & 3.48 & 2.88 \\
Valine & 4.50 & 4.62 & 4.50 & 6.50 & 4.50 & 4.50 & 4.50 \\
Histidine & 2.80 & 2.97 & 2.80 & 2.91 & 2.80 & 2.80 & 2.80 \\
Arginine & 4.76 & 4.92 & 5.76 & 4.83 & 4.71 & 4.56 & 5.03 \\
Aspartic & 7.94 & 8.21 & 8.02 & 8.31 & 8.00 & 7.99 & 8.23 \\
Serine & 3.73 & 3.76 & 3.14 & 2.92 & 3.73 & 3.73 & 3.29 \\
Glutamic & 15.9 & 16.22 & 16.84 & 16.92 & 16.27 & 15.98 & 16.82 \\
Proline & 3.73 & 3.98 & 3.73 & 3.69 & 3.91 & 3.73 & 3.73 \\
Glycine & 4.50 & 4.79 & 4.22 & 6.35 & 5.76 & 4.71 & 4.74 \\
Alanine & 6.44 & 6.83 & 6.44 & 6.21 & 6.83 & 6.44 & 8.65 \\
Tyrosine & 2.41 & 2.95 & 2.41 & 2.38 & 2.80 & 2.39 & 2.52 \\
\hline
\end{tabular}




\section{4- CONCLUSION}

In conclusion, the present results revealed that illumination time regime and illumination colors were significantly affecting the growth of Nile tilapia. A $24 \mathrm{~h}$ illumination and blue illumination were suggested for optimal performance of fish. These results have a significant application in tilapia aquaculture in indoor recirculating systems, as they improve our understanding of the role that illumination time and illumination colors plays in fish growth and metabolism. Adopting the optimum illumination time in case of tilapia will also reduce the amount of energy used for standard metabolism, and in turn increase fish growth and profitability.

\section{REFERENCES}

AOAC (Association of Official Analytical Chemists)., 2000. Official Methods Of Analysis. $17^{\text {Th }}$ Ed. Washington, D.C., USA.

Biswas, A.K., Endo, M., Takeuchi, T., 2002. Effects of different photoperiod cycles on metabolic rate and energy loss of both fed and unfed young tilapia Orochromisniloticus: part I. Fisheries Science 68, 465-477.

Biswas, A.K., Morita, T., Yoshizaki, G., Maita, M., Takeuchi, T., 2005. Control of reproduction in Nile tilapia Oreochromisniloticus (L.) by photoperiod manipulation. Aquaculture 243, 229-239.

Biswas, A.K., Takeuchi, T., 2003. Effects of photoperiod and feeding interval on food intake and growth of Nile tilapia Orochromisniloticus L. Fisheries Science 69, 1010-1016.

Bryan, S.D., Souprir, C.A., Duffy, W.G., Freiburger, C.E., 1996. Caloric densities of three predatory fishes and their prey in lake Oahe, South Dakota. J. Freshw. Ecol. 11, 153-161.

Clement, S., and Lovell, R. T., 1994. Comparison of processing yield and nutrient composition of cultured Nile tilapia (Oreochromis niloticus) and channel catfish (Ictalurus punctatus). Aquaculture, 119(2), 299-310.

El-Sayed, A.F., Kawanna, M., 2004. Effects of photoperiod on the performance of farmed Nile tilapia Oreochromisniloticus: I. Growth, feed utilization efficiency and survival of fry and fingerlings. Aquaculture 231, 393-402. 
El-Sayed, A.M., 2002. Effects of stocking density and feeding levels on growth and feed efficiency of Nile tilapia (Oreochromisniloticus L.). Aquaculture Research 33, 621-626.

Elsbaay, A. M., 2013. Effects of Photoperiod and Different Artificial Light Colors on Nile Tilapia Growth Rate. IOSR Journal of Agriculture and Veterinary Science (IOSR-JAVS). Volume 3, Issue 3, PP 05-12.

FAO, 2005. The State of World Fisheries and Aquaculture. FAO Fish. Aquaculture Department, Rome, Italy

Fuentes-Silva C., G.M. Soto-Zarazua, I. Torres-Pacheco, R.G. GuevaraGonzález, J.F. García-Trejo, A. Flores-Rangel, J. Caballero-Pérez and A. Cruz-Hernández, 2015. Influence of Extended Photoperiod on All Male Nile Tilapia (Oreochromis niloticus) Production, Differential Gene Expression and Growth Rate. INTERNATIONAL JOURNAL OF AGRICULTURE \& BIOLOGY. ISSN Print: 1560-8530; ISSN Online: 1814-9596.

Garduno-Lugo, M., Granados-Alvarez, I., Olvera-Novoa, M. A., and Muñoz-Córdova, G., 2003. Comparison of growth, fillet yield and proximate composition between Stirling Nile tilapia (wild type)(Oreochromis niloticus, Linnaeus) and red hybrid tilapia (Florida red tilapiax Stirling red O. niloticus) males. Aquaculture Research, 34(12), 1023-1028.

Hu, C. J., Chen, S. M., Pan, C. H. \& Huang, C. H. (2006). Effects of dietary vitamin $\mathrm{A}$ or $\beta$-carotene concentrations on growth of juvenile hybrid tilapia, Oreochromis niloticus x $O$. aureus. Aquaculture 253, 602-607.

Jentoft, S., Oxnevad, S., Aastveit, A.H., Andersen, O., 2006. Effects of tank wall color and up-welling water flow on growth and survival of Eurasian perch larvae (Percafluviatilis). J. World Aquac. Soc. 37, 313-317.

Karakatsouli, N., Papoutsoglou, S.E., Panopoulos, G., Papoutsoglou, E.S., Chadio, S., Kalogiannis, D., 2008. Effects of light spectrum on growth and stress response of rainbow trout Oncorhynchusmykiss reared under recirculating system conditions. Aquacult. Eng. 38, $36-42$. 
Karakatsouli,N., Papoutsoglou,S.E., Sotiropoulos, N, StigenMartinsen,T.D.N., Sofronios E. Papoutsoglou, E. S., 2010. Effects of light spectrum, rearing density and light intensity on growth performance of scaled and mirror common carp Cyprinuscarpio reared under recirculating system conditions. Aquacultural Engineering 42 (2010) 121-127.

Krishen, J.R., S. Sunil and R.H. Mohammad, 2009. Impact of Rising Feed Ingredient Prices on Aquafeeds and Aquaculture Production. No. 541, Food and Agriculture Organization of the United Nations (FAO), Rome, Italy.

Kristinsson, H. G., and Rasco, B. A., 2000. Fish protein hydrolysates: production, biochemical, and functional properties. Critical reviews in food science and nutrition, 40(1), 43-81.

Lara-Flores, M., Olvera-Novoa, M. A., Guzm'an-M'endez, B. E. \& L'opez-Madrid, W. (2003). Use of the bacteria Streptococcus faecium, Lactobaccillus acidophilus, and the yeast Saccharomyces cerevisiae as growth promoters in Nile tilapia (Oreochromis niloticus). Aquaculture 216, 193-201.

Larsson, S., Berglund, I., 2005. The effect of temperature on the energetic growth efficiency of Arctic charr (Salvelinusalpinus L.) from four Swedish populations. J. Therm. Biol. 30, 29-36.

Luchiari, A.C., Freire, F.A.M., 2009. Effects of environmental colour on growth of Nile tilapia, Oreochromisniloticus (Linnaeus, 1758), maintained individually or in groups. J. Appl. Ichthyol. 25, 162167.

Pellet, P. C. and Young, V. R.,1980. Nutritional Evaluation of Protein Foods. The United Nations University Book, New York, USA.

Pointer, M.A., Cheng, C.-H.C., Bowmaker, J.K., Parry, J.W.L., Soto, N., Jeffery, G., Purchase, C.F., Boyce, D.L., Brown, J.A., 2005. Growth and survival of juvenile yellowtail flounder (Pleuronectesferrugineus Storer) under different photoperiods. Aquaculture Research 31, 547-552.

Purchase, C. F., Boyce, D. L. \& Brown, J. A. (2000). Growth and survival of juvenile flounder Pleuronectes ferrugineus (Storer) under different photoperiods. Aquaculture Research 31, 547-552. 
Rad, F., Bozaoğlu, S., Gözükara, S. E., Karahan, A. and Kurt, G., 2006. Effects of different long-day photoperiods on somatic growth and gonadal development in Nile tilapia (Oreochromis niloticus L.). Aquaculture, 255(1), 292- 298.

Strand, Å.,Magnhagen, C., Alanärä, A., 2007. Effects of repeated disturbances on feed intake, growth rates and energy expenditures of juvenile perch, Percafluviatilis. Aquaculture 265, 163-168.

Vera Cruz, E. M. and C. L. Brown, 2009. Influence of the photoperiod on growth rate and insulin-like growth factor-I gene expression in Nile tilapia Oreochromis niloticus. Journal of Fish Biology, 75, 130141.

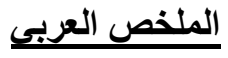

تأثير ألون الاضاءة الصناعية وفترات الاضاءة علي معدل النمو وجودة لحم المي المئي

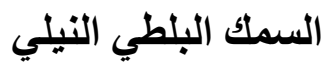

عاطن محمد السباعي'

تهدف هذه الدراسة الي اختبار تأثثير الفترات الضوئية وكذلك لون الضوء علي نمو ونشاط وجودة الضاطي لحم اسماك البلطي (Tilapia Niloticus) . حيث تم تغذية التية الاسماك الثناء التجربة علئ علي العليقة

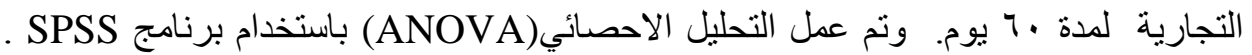

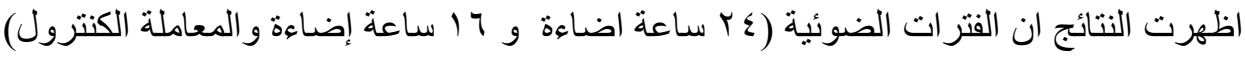

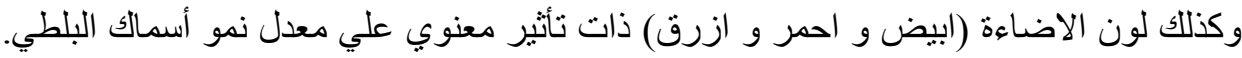

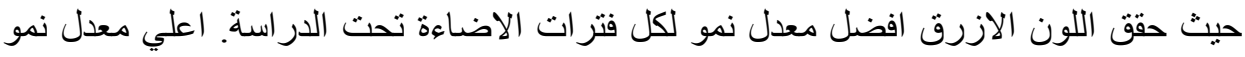

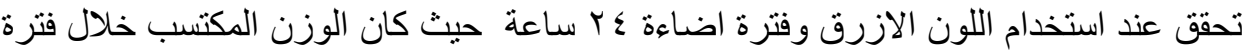

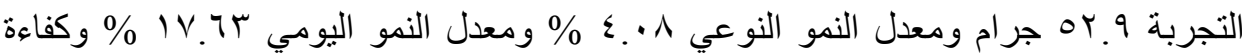

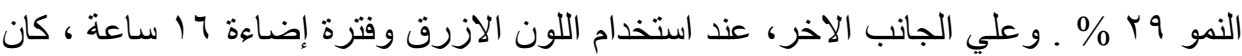

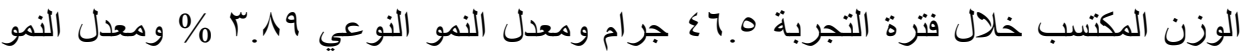

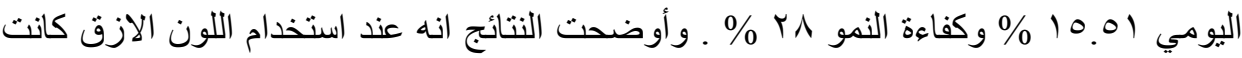

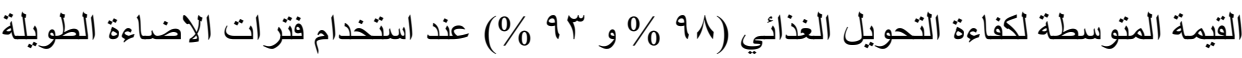

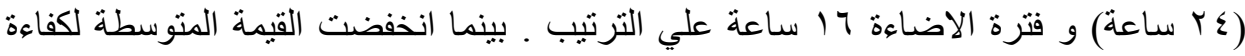

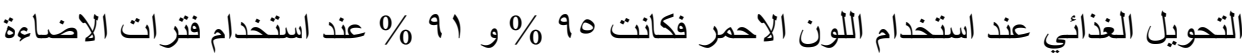

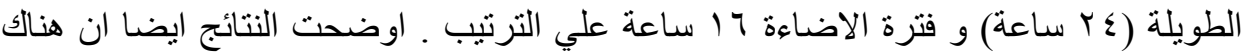

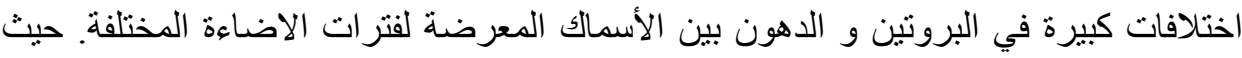

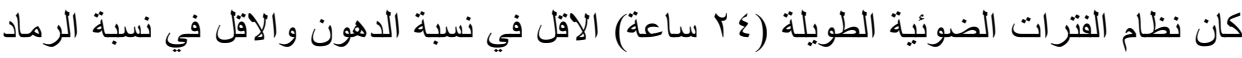
و الاعلي في نسبة البروتين.

'مدرس الهندسة الزراعية ـ قسم الهندسة الزراعية ـ كلية الزراعة ـ جامعة كفر الشيخ. 